\title{
Seagrass as major source of transparent exopolymer particles in the oligotrophic Mediterranean coast
}

\author{
Francesca Iuculano $^{1}$, Carlos Maria Duarte ${ }^{2}$, Núria Marbà ${ }^{1}$, and Susana Agustí ${ }^{2}$ \\ ${ }^{1}$ Department of Global Change Research, Instituto Mediterráneo de Estudios Avanzados (IMEDEA), \\ CSIC-UIB, Esporles, 07190, Balearic Islands, Spain \\ ${ }^{2}$ King Abdullah University of Science and Technology (KAUST), Red Sea Research Center (RSRC), \\ Thuwal, 23955-6900, Saudi Arabia
}

Correspondence to: Francesca Iuculano (fiuculano@imedea.uib-csic.es)

Received: 23 December 2016 - Discussion started: 9 January 2017

Revised: 5 September 2017 - Accepted: 24 September 2017 - Published: 15 November 2017

\begin{abstract}
The role of seagrass, Posidonia oceanica, meadows as a source of transparent exopolymer particles (TEPs) to Mediterranean coastal waters was tested by comparing the TEP dynamics in two adjacent coastal waters in the oligotrophic NW Mediterranean Sea, one characterized by oligotrophic open-sea waters and the other accumulating seagrass leaf litter, together with an experimental examination of TEP release by seagrass litter. TEP concentrations ranged from 4.6 to $90.6 \mu \mathrm{g} \mathrm{XG}$ (xanthan gum) $\mathrm{EqL}^{-1}$, with mean $( \pm \mathrm{SE})$ values of $38.7( \pm 2.02) \mu \mathrm{g} \mathrm{XEq} \mathrm{L}^{-1}$ in the site devoid of seagrass litter, whereas the coastal beach site accumulating leaf litter had $>10$-fold mean TEP concentrations of $487.02( \pm 72.8) \mu \mathrm{g} \mathrm{XG} \mathrm{Eq} \mathrm{L}{ }^{-1}$. Experimental evaluation confirmed high rates of TEP production by $P$. oceanica litter, allowing calculations of the associated TEP yield. We demonstrated that $P$. oceanica is an important source of TEPs to the Mediterranean Sea, contributing an estimated $76 \mathrm{Gg} \mathrm{C}$ as TEPs annually. TEP release by $P$. oceanica seagrass explains the elevated TEP concentration relative to the low chlorophyll $a$ concentration in the Mediterranean Sea.
\end{abstract}

\section{Introduction}

Transparent exopolymer particles (TEPs) are acidic and sulfated polysaccharides enriched in deoxy sugars and galactose (Myklestad, 1995) which are stainable with alcian blue (Alldredge et al., 1993). These organic particles belong to the POC (particulate organic carbon) pool (Zhou et al., 1998) and are ubiquitous in marine and limnetic ecosystems (Pas- sow, 2002). Their roles in several biogeochemical processes and their importance in sedimentary carbon fluxes has been extensively documented (Engel and Passow, 2001) as, due to its sticky properties, the aggregation of these particles may enhance the sinking flux and export of organic matter (Kiørboe and Hansen, 1993; Simon et al., 2002) with important consequences for the efficiency of the biological carbon pump (Mari et al., 2017, and references therein). Phytoplanktonic cells, mainly diatoms, are believed to be the major sources of TEPs in the marine environment (Passow and Alldredge, 1995a), although benthic organisms, such as suspension feeders (Heinonen et al., 2007) and macroalgal detritus (Thornton, 2004), have been also identified as TEP sources. Indeed, marine macrophytes are important sources of dissolved organic carbon (DOC) to coastal waters (Barrón et al., 2006) and may therefore release precursors conducive to TEP formation, such as reported by Thornton (2004) for macroalgae. However, seagrass meadows are also important sources of DOC to the marine environment (Barrón et al., 2014), but their role as a source of TEPs has not yet been assessed.

Posidonia oceanica Delile (L.) is the dominant seagrass species of the Mediterranean Sea (Duarte, 2004). P. oceanica meadows are highly productive (Duarte and Chiscano, 1999) and release high amounts of dissolved organic carbon (Barrón et al., 2014) as well as leaf litter (Cebrian and Duarte, 2001; Gacia et al., 2002). The large production of DOC and detritus by $P$. oceanica contrasts with the low planktonic primary production in the oligotrophic Mediterranean littoral zone (Duarte et al., 1999), where TEPs are 
nevertheless present (Mari et al., 2001; Beauvais et al., 2003; Prieto et al., 2006; Ortega-Retuerta et al., 2010; Bar-Zeev et al., 2011) at levels higher than expected, as indicated by high TEP / Chl $a$ and TEP/bacterial abundance ratios compared to other marine systems (Ortega-Retuerta et al., 2010, 2017). Whereas TEPs are often assumed to be of phytoplankton origin, the relatively high levels of TEPs (i.e. high TEP / Chl $a$ ratios) in oligotrophic Mediterranean waters suggest that DOC release by Posidonia oceanica meadows could be a source of TEPs, explaining the relative high TEP concentration reported for Mediterranean waters (Ortega-Retuerta et al., 2010). Although macroalgae have been identified as sources of TEPs, we are not yet aware of any study examining the role of seagrass as source of TEPs. In this study, we monitored the dynamics of TEP concentrations in two adjacent, but contrasting, oligotrophic littoral sites of Majorca (NW Mediterranean Sea), an open coastline flushed with open seawaters and an adjacent, $2 \mathrm{~km}$, beach accumulated Posidonia oceanica leaf litter. We tested the hypothesis that seagrass leaf litter of $P$. oceanica represents an important source of TEPs to this ecosystem, explaining the contrasting TEP concentrations and dynamics observed in these coastal sites using a laboratory experiment.

\section{Materials and methods}

\subsection{Sampling sites and time-series observations}

The study was carried out at two sites on the coast of the island of Majorca, Balearic Islands, NW Mediterranean Sea:

- the Faro Cap Ses Salines experimental field station (lat $39.264724^{\circ} \mathrm{N}$, long $3.054446^{\circ} \mathrm{E}$ ), where TEP concentrations were monitored fortnightly for 3 years starting in January 2012. This is a pristine and oligotrophic rocky shore ecosystem, with an extensive seagrass of P. oceanica meadow extended around $500 \mathrm{~m}$ offshore (Álvarez et al., 2015) and flushed with open-sea water (Fig. 1a).

- Es Caragol beach (lat $39.276784^{\circ} \mathrm{N}$, long $3.043779^{\circ} \mathrm{E}$ ), where TEP dynamics were monitored for 2 years starting in August 2012. This is a natural sandy beach at a site of community importance (EU directive-red natura2000) where abundant seagrass detritus accumulates on the shore (Fig. 1b), where it plays an important geomorphological role (Simeone and De Falco, 2012).

Surface water samples at Faro Cap Ses Salines and Es Caragol were collected fortnightly (monthly during winter months) in 2 L Nalgene bottles at noon and 15:00, respectively. A total of 76 sampling events were completed at Faro Cap Ses Salines between 9 January 2012 and 23 March 2015, while 45 sampling events were completed at Es Caragol (from 9 August 2012 to 24 September 2014). Surface seawater samples of $250 \mathrm{~mL}$ from Faro Cap Ses Salines for
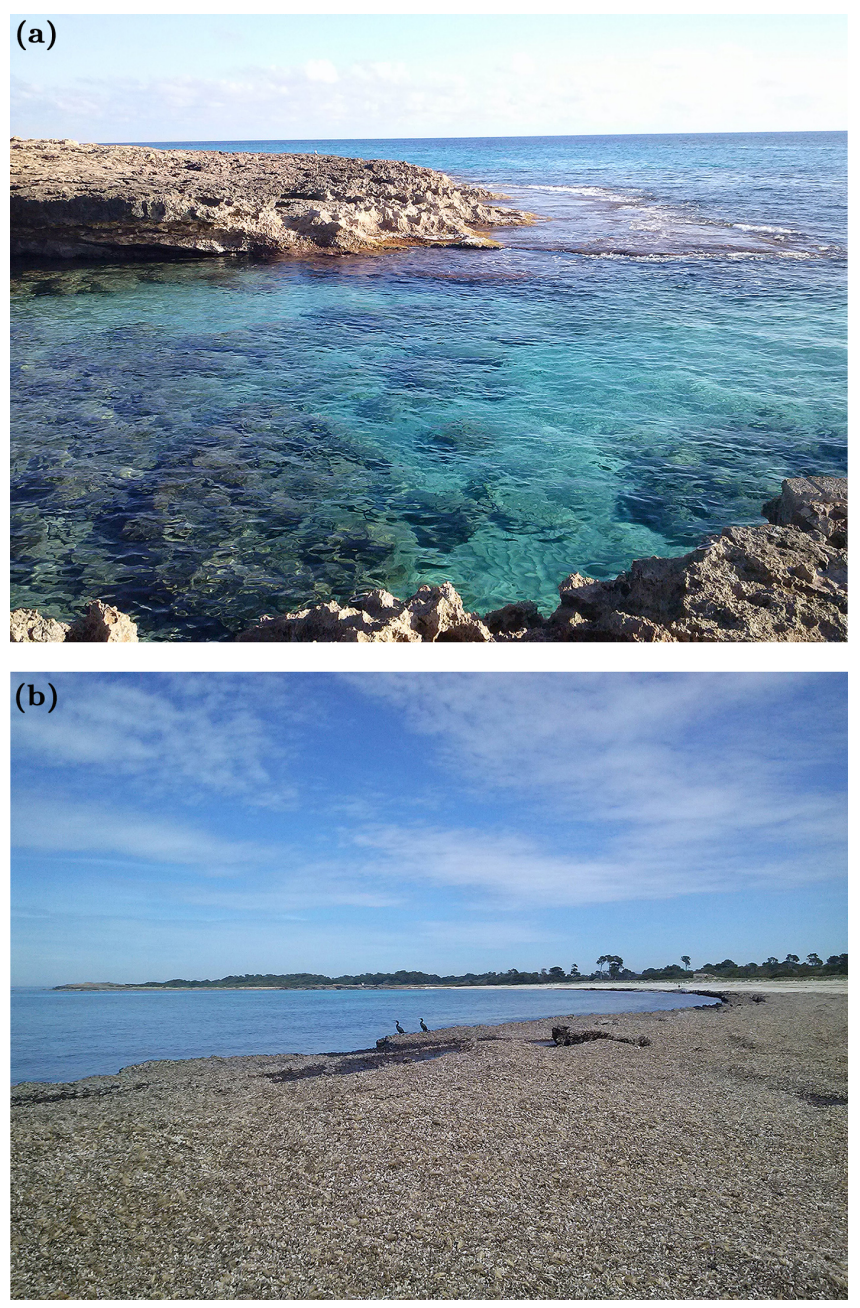

Figure 1. The two sites monitored at Cap Ses Salines (a) and at Es Caragol beach (b), Majorca, NW Mediterranean Sea.

chlorophyll $a$ determination were filtered through Whatman $\mathrm{GF} / \mathrm{F}$ filters and stored at $-20^{\circ} \mathrm{C}$. Filters were extracted in $6 \mathrm{~mL} 90 \%$ acetone for $24 \mathrm{~h}$ followed by fluorometric (Trilogy, Turner design) Chl $a$ determination, calibrated with pure Chl $a$, after Parsons et al. (1984). Sea-surface temperature was measured in situ using a data logger (HOBO).

TEP concentrations were determined following the colorimetric method of Passow and Alldredge (1995b), where TEPs are detected after staining with alcian blue (Sigma), a cationic copper phthalocyanine dye that complexes carboxyl (-COO-) and half-ester sulfate $\left(\mathrm{OSO}_{3}^{-}\right)$reactive groups of acidic polysaccharides. Following each sampling event, triplicate aliquots (Faro Cap Ses Salines: $300-700 \mathrm{~mL}$; Es Caragol: $50-500 \mathrm{~mL}$, depending on the saturation of filters) were filtered through $0.4 \mu \mathrm{m}$ pore size, $25 \mathrm{~mm}$ diameter polycarbonate filters under low and constant pressure $(150 \mathrm{~mm} \mathrm{Hg})$. Filters were subsequently stained with $1000 \mu \mathrm{L}$ of a $0.02 \%$ working solution of alcian blue (prefiltered through $0.2 \mu \mathrm{m})$ in $0.06 \%$ acetic acid $(\mathrm{pH}=2.5)$, al- 
lowed to stain for a few seconds, repeated filtering and rinsed twice with Milli-Q water, to eliminate excess dye. Dyed filters were stored at $-80^{\circ} \mathrm{C}$ until extraction at IMEDEA laboratory. To perform the extraction, filters were placed in acidcleaned $10 \mathrm{~mL}$ glass tubes, by adding $5 \mathrm{~mL}$ of $80 \%$ sulfuric acid, for 2 to $3 \mathrm{~h}$, shaking two to three times to enhance extraction. Absorbance was read spectrophotometrically (Shimadzu dual-beam spectrophotometer) at $787 \mathrm{~nm}$ in $1 \mathrm{~cm}$ disposable cuvettes. Triplicate blank filters were also analysed for every batch of samples. Blank absorbance values at $787 \mathrm{~nm}$ were then subtracted from the total absorbance values of samples, to account for the capacity of alcian blue to stain filters. Four calibrations of the alcian blue solutions were performed by using xanthan gum as standard $(\mathrm{XG})$. The calibration factor $(F)$ was calculated as the mean of the eight estimates obtained. TEP concentrations (TEP) were expressed in $\mu \mathrm{g}$ xanthan gum $(\mathrm{XG})$ equivalents per litre ( $\mu \mathrm{g} \mathrm{XG} \mathrm{Eq} \mathrm{L}^{-1}$ ) and calculated following Eq. (1):

$\mathrm{TEP}=\left(a_{\text {sample }}-a_{\text {blank }}\right) V^{-1} \times F$,

where $a_{\text {sample }}$ and $a_{\text {blank }}$ are absorbance values at $787 \mathrm{~nm}$ for samples and blank filters, respectively; $V$ is the sampled volume (in L) and $F$ is the calibration factor. The detection limit of the method was $2.2 \mu \mathrm{g} \mathrm{XG} \mathrm{Eq} \mathrm{L}{ }^{-1}$, and the analytical coefficient of variation was $13 \%$. TEP concentrations were transformed to carbon units $\left(\mu \mathrm{g} \mathrm{CL}^{-1}\right)$ by using the conversion factor of 0.75 proposed by Engel and Passow (2001) in order to estimate the total TEP yield of $P$. oceanica leaf litter.

\subsection{Experimental evaluation of TEP release by $P$. oceanica leaf litter}

$P$. oceanica leaf litter and surface seawater were sampled on 8 September 2014 , the period of leaf shedding for $P$. oceanica, from the seashore of Es Caragol and stored at $4{ }^{\circ} \mathrm{C}$ for transport to the laboratory. Six $5 \mathrm{~L}$ Pyrex glass bottles were filled with seawater, pre-filtered by gravity through a $0.2 \mu \mathrm{m}$ pore membrane size cartridge filter. Three replicated bottles received $16.6 \mathrm{mg}$ fresh weight $\mathrm{L}^{-1}$ of $P$. oceanica leaf litter, to obtain a final concentration similar to that measured in the nearshore waters at Es Caragol, and three replicated bottles, without $P$. oceanica leaf litter, were used as control. The bottles were gently aerated with an air pump to provide mixing and avoid the development of anoxic conditions. The bottles were incubated at the in situ temperature at the time of sampling $\left(26.3^{\circ} \mathrm{C}\right)$ in a temperature-controlled chamber, and water samples of TEP determinations were collected at increasing time intervals: time 0 (11 September), 6, 12, 24, 48 , and $264 \mathrm{~h}$ (22 September) after the start of the experiment. The water volume and leaf biomass (fresh weight and dry weight following desiccation at $60^{\circ} \mathrm{C}$ for $24 \mathrm{~h}$ in a drying oven) in the bottles were measured. Replicated 50 to $100 \mathrm{~mL}$ volumes, pre-filtered through a $100 \mu \mathrm{m}$ mesh to remove leaf litter, were sampled using a $60 \mathrm{~mL}$ syringe and immediately filtered through $0.4 \mu \mathrm{m}$ to collect, dye, and quantify TEP con- centration following the procedure described above (Passow and Alldredge, 1995b).

\section{Results}

Surface seawater temperature ranged from 12.4 to $27.8^{\circ} \mathrm{C}$, registered in February 2012 and September 2014, respectively, during the study (average $\pm \mathrm{SE}=19.4 \pm 0.54{ }^{\circ} \mathrm{C}$ ). Chlorophyll $a$ concentration ranged from 0.02 to $0.54 \mu \mathrm{g} \mathrm{L}^{-1}$ in July 2014 and March 2013, respectively, during the study (average $\pm \mathrm{SE}=0.23 \pm 0.01 \mu \mathrm{g} \mathrm{L}^{-1}$ ).

TEP concentrations ranged from 4.6 to $90.6 \mu \mathrm{g} \mathrm{XG} \mathrm{Eq} \mathrm{L}{ }^{-1}$ in Faro Cap Ses Salines and from 26.8 to $1878.4 \mu \mathrm{g} \mathrm{XGEL} \mathrm{L}^{-1}$ in Es Caragol, with significantly (paired $t$ test, $p<0.05$ ) higher mean TEP concentrations at Es Caragol $\left(38.7 \pm 2.02 \mu \mathrm{g} \mathrm{XGEqL}{ }^{-1}\right)$ compared to Faro Cap Ses Salines $\left(487.02 \pm 72.8 \mu \mathrm{g} \mathrm{XGEL} \mathrm{L}^{-1}\right)$. TEP concentrations changed greatly seasonally, with maximum TEP values in waters sampled at the Faro Cap Ses Salines observed in February, likely associated with the phytoplankton bloom occurring at that time, and June (Fig. 2a). In contrast, TEP dynamics showed a more erratic temporal pattern at Es Caragol, with no clear seasonal patterns (Fig. 2b). Mean $( \pm \mathrm{SE})$ TEP / Chl $a$ ratios were also $>10$-fold greater at Es Caragol (3109.9 \pm 468.9$)$ than at the Faro Cap Ses Salines $(286.3 \pm 55.7)$, with a clear seasonal cycle characterized by maximum TEP / Chl $a$ ratios in June and July at the Faro Cap Ses Salines, whereas at Es Caragol they remained elevated throughout the year, except between January and March when values were relatively low (Fig. 3a, b).

During the experimental evaluation initial TEP concentrations $\left(30.4 \mu \mathrm{g} \mathrm{XGEq} \mathrm{L}{ }^{-1}\right)$ increased slightly after $6 \mathrm{~h}$ incubation, to remain uniform throughout the rest of the experiment in the absence of $P$. oceanica leaf litter (Fig. 4). In contrast, TEP concentrations increased greatly throughout the experiment in the presence of $P$. oceanica litter, reaching values of $1551 \mu \mathrm{g} \mathrm{XGE} \mathrm{L} \mathrm{L}^{-1}$, comparable to maximum values observed at Es Caragol, after $264 \mathrm{~h}$ (Fig. 4). The corresponding TEP yield of $P$. oceanica corresponded to $14.128 \pm 11.294 \mu \mathrm{g} \mathrm{XG} \mathrm{Eq} \mathrm{L}^{-1}$ or

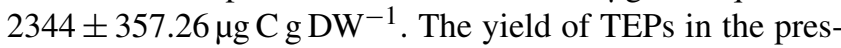
ence of $P$. oceanica litter was 9.77 times greater than that in control bottles $\left(1.384 \pm 1.582 \mu \mathrm{g} \mathrm{XG} \mathrm{Eq} \mathrm{L}{ }^{-1}\right)$.

\section{Discussion}

The results presented provide, to the best of our knowledge, the first evidence that seagrass leaf litter is a source of TEPs to coastal waters. Thornton (2004) demonstrated the formation of TEPs from the acidic polysaccharides released by macroalgal detritus of different species, but the role of seagrass litter as a source of TEPs has not been reported to date. The role of $P$. oceanica leaf litter as a source of TEPs is demonstrated here through the $>10$-fold difference 


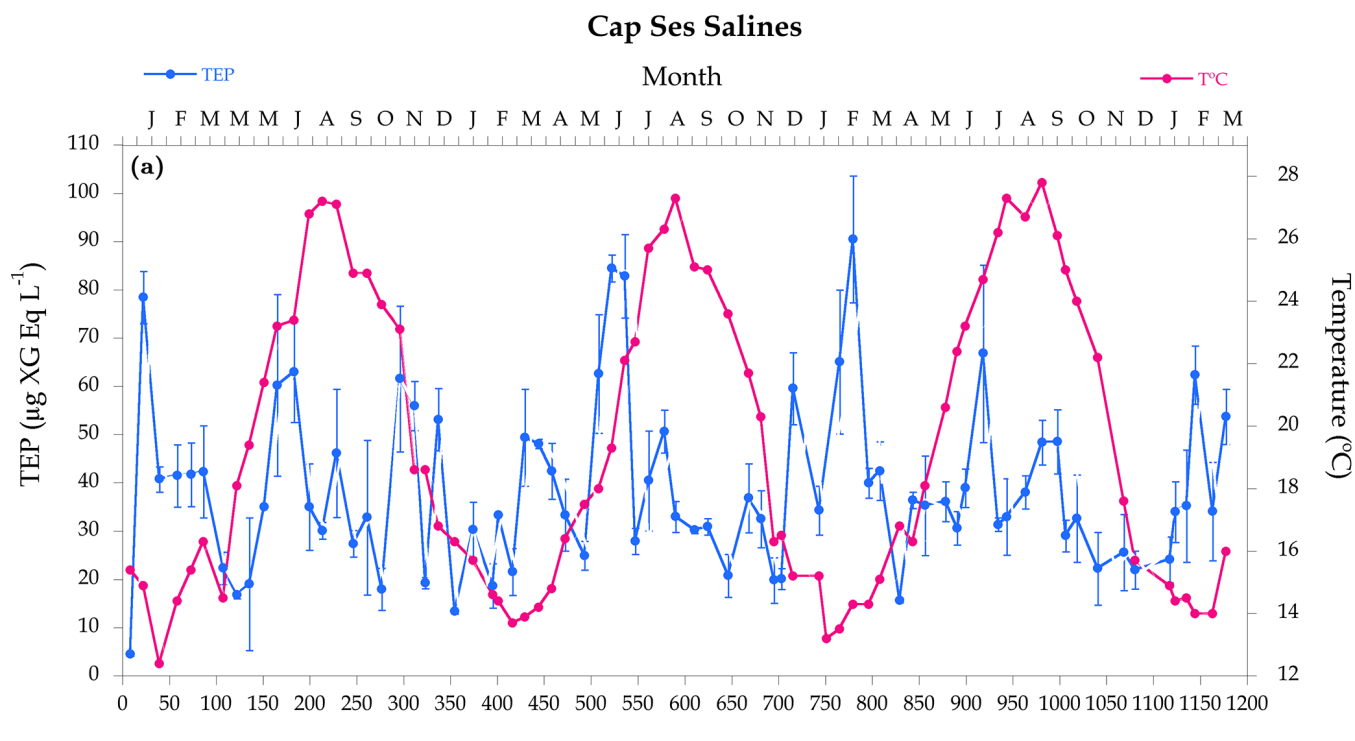

Julian Day (since 1 Jan 2012)

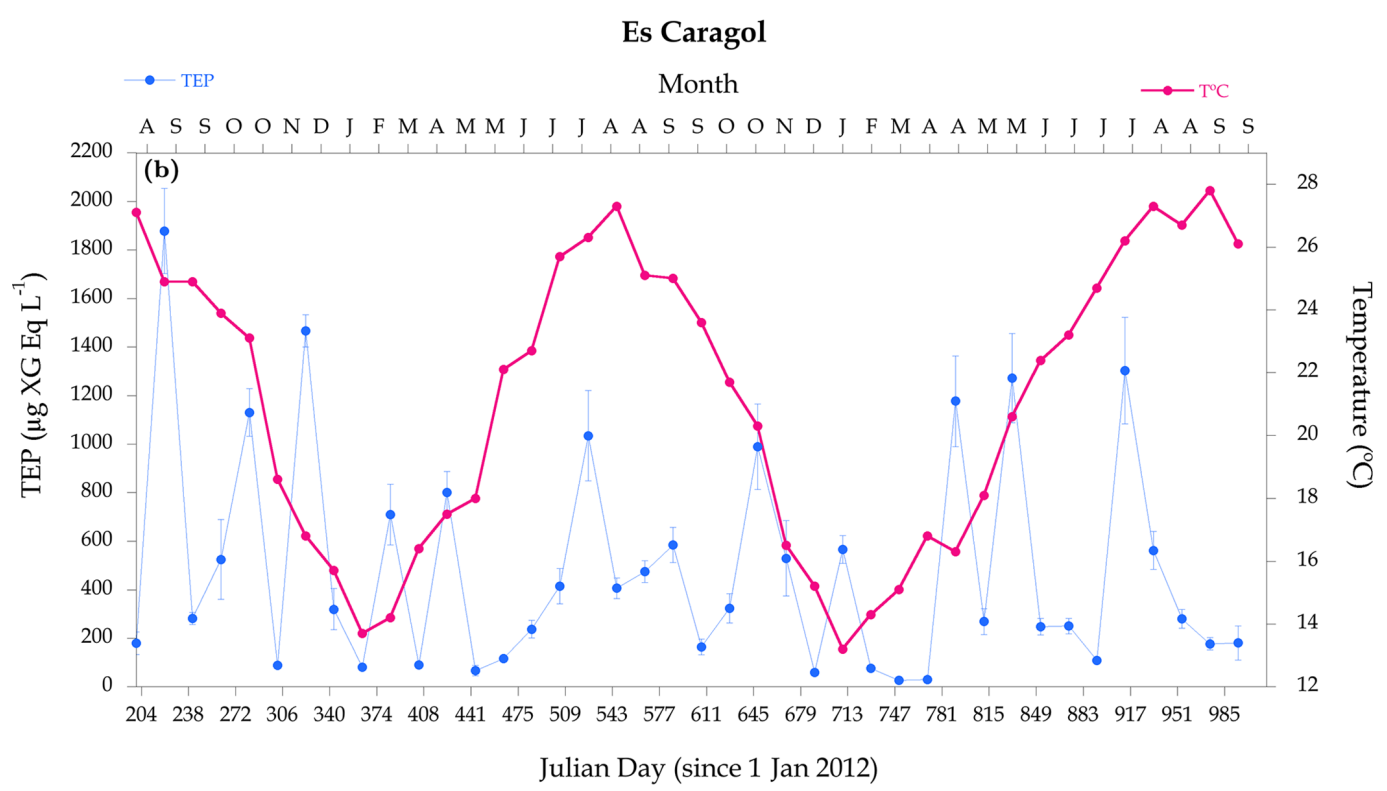

Figure 2. Time series of TEP concentrations $\left(\mu \mathrm{g} \mathrm{XGEqL}{ }^{-1} \pm \mathrm{SE}\right)$ and temperature $\left({ }^{\circ} \mathrm{C}\right)$ at Cap Ses Salines (a) and Es Caragol beach (b).

in concentration and TEP / Chl $a$ ratios between the two adjacent coastal areas studied, one containing rapidly flushed open-sea water and the other representing an accumulation site for $P$. oceanica leaf litter. The experimental evidence reported further confirms the role of TEPs formed by precursors released by $P$. oceanica leaf litter, together with the associated microbial heterotrophic community (Peduzzi and Herndl, 1991), in explaining the differences between the two sites, as the TEP concentration reached, using a concentration of leaf litter similar to that observed in Es Caragol, is comparable to the maximum values observed in situ.
P. oceanica, as well as seagrasses in general, exports a large fraction of its net primary production as leaf litter, on average about $24 \%$ of net primary production (Duarte and Cebrián, 1996). A fraction of this leaf litter is exported to the shoreline following leaf shedding by $P$. oceanica in the late summer and early autumn (Mateo et al., 2003). Leaf litter is then deposited on the beach and re-entrained in the water during storms, resulting in the pulses of TEPs observed at Es Caragol.

The seasonal variability in TEP / Chl $a$ ratios at Faro Cap Ses Salines, where leaf litter accumulation is precluded by strong currents, shows a maximum in the summer (June and 

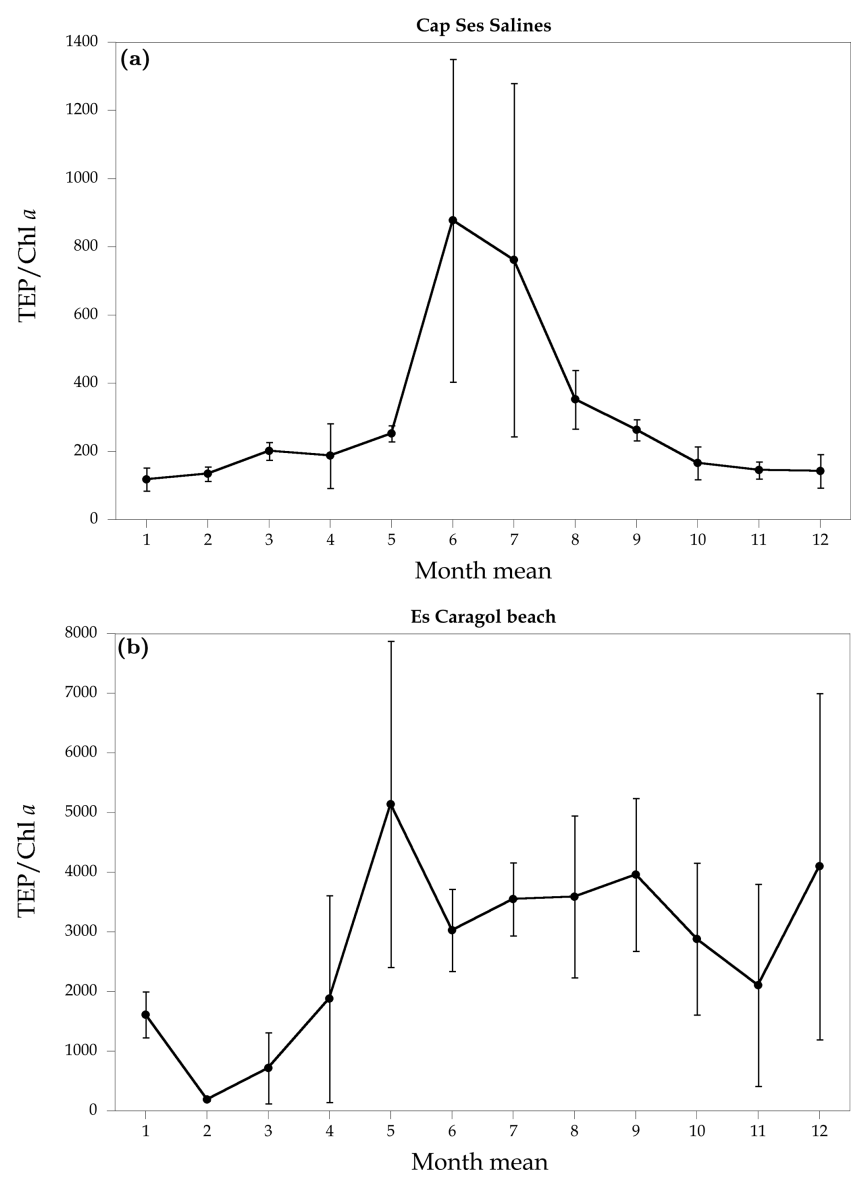

Figure 3. Monthly TEP / Chl $a$ ratios means \pm SE at Cap Ses Salines (a) and Es Caragol beach (b).

July), likely resulting from TEP precursors released by the nearby seagrass meadow. Ortega-Retuerta et al. (2010) already reported elevated TEP / Chl $a$ ratios during early summer in the Mediterranean Sea, with values comparable to those we observe at the Faro Cap Ses Salines.

These observations suggest that $P$. oceanica meadows, the dominant ecosystem in Mediterranean coastal waters, are an important source of TEP precursors in the Mediterranean Sea (Ortega-Retuerta et al., 2010). Considering the average leaf production of $P$. oceanica of $876 \mathrm{~g} \mathrm{DW} \mathrm{m}^{-2}$ $\mathrm{y}^{-1}$ (Duarte and Chiscano, 1999), the estimated $37000 \mathrm{~km}^{2}$ covered by $P$. oceanica in the Mediterranean Sea (range 31040 to $43550 \mathrm{~km}^{2}$, Marbà et al., 2014) and the average TEP yield from leaf litter experimentally derived here

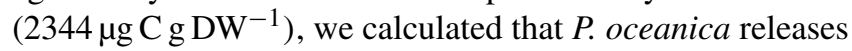
about $76 \mathrm{Gg} \mathrm{C}$ as TEPs annually to the Mediterranean Sea. However, this estimate should be considered a first-order estimate, as it involves considerable uncertainty, compounding that derived from the substantial variability in primary production of P. oceanica (Duarte and Chiscano, 1999), that in the area covered by $P$. oceanica meadows in the Mediterranean Sea, and variability in TEP yield across meadows

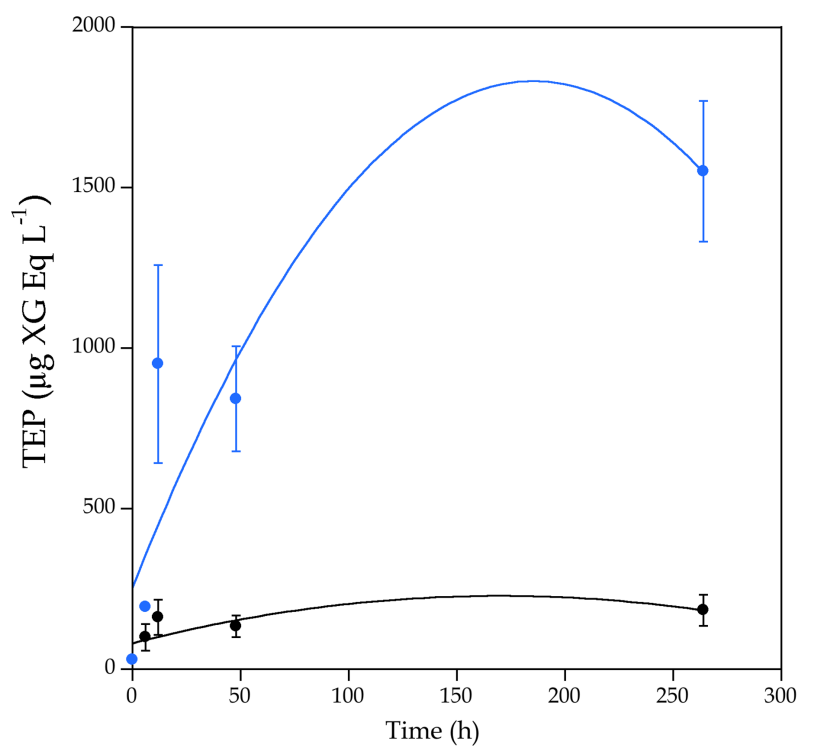

Figure 4. TEP accumulation (mean $\pm \mathrm{SE}$ ) in the presence (blue line) and absence (dark line) of $P$. oceanica litter. The solid lines show the fitted second-order polynomial equations $\left(R^{2}=0.77\right.$ and 0.53 , respectively).

and over time, as the estimate used was derived from a single meadow in the autumn. Improving this estimate will require narrowing down these sources of uncertainty as well as the capacity to compare it with estimates of other sources of TEPs, such as phytoplankton, which are not yet available at the basin scale. The contribution of $P$. oceanica meadows to TEP release may contribute to explain, along with other processes, the elevated TEP / Chl $a$ ratios characteristic of the Mediterranean Sea (Ortega-Retuerta et al., 2010). The role of $P$. oceanica as a relevant source of TEP precursors is enhanced by the contrast between the high production of P. oceanica meadows (Duarte and Chiscano, 1999), resulting in a high production of detritus (e.g. Mateo and Romero, 1997; Cebrián and Duarte, 2001) releasing TEP precursors, and the oligotrophic nature of the Mediterranean Sea, leading to low production in the pelagic compartment. In fact, both P. oceanica (e.g. Alcoverro et al., 1997) and phytoplankton (e.g. Krom et al. 1991) are likely to be strongly nutrientlimited in the Mediterranean Sea, which has been shown to enhance the release of TEP precursors through carbon overflow during nutrient limiting conditions (Mari et al., 2001; Radić et al., 2005). Despite the limitations acknowledged above, estimates highlight the important role of P. oceanica litter as source of TEPs in the Mediterranean and suggest that seagrass meadows may play a similarly important role in other regions supporting extensive seagrass meadows, such as the Caribbean, Australia, and South East Asia.

Seagrass meadows have been recently shown to be globally relevant sources of DOC to the marine ecosystem (Barrón et al., 2014), and Mari et al. (2017) have recently as- 
sessed that the global TEP production could represent 2.5 to $5 \mathrm{Pg} \mathrm{C} \mathrm{yr}^{-1}$. Here we provide the first evidence that seagrass meadows can also play a relevant, even locally dominant, role as sources of TEPs and, therefore, for the particle dynamics in the ocean. This finding has important biogeochemical implications and provides a new pathway to be accounted for when considering the fate and fluxes of organic matter in the continuum of DOM-POM bridge.

Data availability. All relevant data are presented within the paper.

Competing interests. The authors declare that they have no conflict of interest.

Acknowledgements. This work is a contribution to the StressX project, funded by the Spanish Ministry of Economy and Innovation (CTM2012-32603). Francesca Iuculano was supported by JAE predoctoral fellowship from the Consejo Superior de Investigaciones Científicas (CSIC). We thank Juan de la Cruz Martinez Ayala for help with sampling and $\mathrm{Chl} a$ measurements.

Edited by: Gerhard Herndl

Reviewed by: two anonymous referees

\section{References}

Alcoverro, T., Romero, J., Duarte, C. M., and López, N. I.: Spatial and temporal variations in nutrient limitation of seagrass Posidonia oceanica growth in the NW Mediterranean, Mar. Ecol.-Prog. Ser., 146, 155-161, 1997.

Alldredge, A. L., Passow, U., and Logan, B. E.: The abundance and significance of a class of large, transparent organic particles in the ocean, Deep-Sea Res. Pt. I, 40, 1131-1140, 1993.

Álvarez, E., Grau, A. M., Marbà, N., and Carreras D.: Las praderas de angiospermas marinas de las Islas Baleares, in: Atlas de praderas marinas de España, Ruiz, J. M., Guillén, E., Ramos Segura, A., and Otero, M. M., IEO/IEL/UICN, Murcia-Alicante-Málaga, 179-219, available at: http://www.ieo. es/documents/10192/26809/Atlas-praderas-marinas-de-Espa\% C3\%B1a-244-1.pdf/ee4e0dd6-e30c-443e-a6dd-14cc445068ad (last access: 14 November 2017), 2015.

Barrón, C., Duarte, C. M., Frankignoulle, M., and Borges Vieira, A.: Organic Carbon Metabolism and Carbonate Dynamics in a Mediterranean Seagrass (Posidonia oceanica) Meadow, Estuar. coast., 29, 417-426, https://doi.org/10.1007/BF02784990, 2006.

Barrón, C., Apostolaki, E. T., and Duarte, C. M.: Dissolved organic carbon fluxes by seagrass meadows and macroalgal beds, Front. Mar. Sci., 1, 1-11, https://doi.org/10.3389/fmars.2014.00042, 2014.

Bar-Zeev, E., Berman, T., Rahav, E., Dishon, G., Herut, B., and Berman-Frank, I.: Transparent exopolymer particle (TEP) dynamics in the eastern Mediterranean Sea, Mar. Ecol.-Prog. Ser., 431, 107-118, https://doi.org/10.3354/meps09110, 2011.
Beauvais, S., Pedrotti, M., Villa, E., and Lemée, R.: Transparent exopolymer particle (TEP) dynamics in relation to trophic and hydrological conditions in the NW Mediterranean Sea, Mar. Ecol.Prog. Ser., 262, 97-109, https://doi.org/10.3354/meps262097, 2003.

Cebrian, J. and Duarte, C. M.: Detrital stocks and dynamics of the seagrass Posidonia oceanica (L.) Delile in the Spanish Mediterranean, Aquat. Bot., 70, 295-309, https://doi.org/10.1016/S0304-3770(01)00154-1, 2001.

Duarte, C. M.: How can beaches managed with respect to seagrass litter?, in: European seagrasses: an introduction to monitoring and management, edited by: Borum, J., Duarte, C. M., Krause Jensen, D., and Grevr, T. M., The M\&MS proyect, 8384, online, available at: http://www.seagrasses.org/handbook/ european_seagrasses_high.pdf (last access: 14 November 2017), 2004.

Duarte, C. M. and Cebrián, J.: The fate of marine autotrophic production, Limnol. Oceanogr., 41, 1758-1766, 1996.

Duarte, C. M. and Chiscano, C. L.: Seagrass biomass and production: a reassessment, Aquat. Bot., 65, 159-174, https://doi.org/10.1016/S0304-3770(99)00038-8, 1999.

Duarte, C. M., Kennedy, H., Agustí, S., and Vaqué, D.: The Mediterranean climate as a template for Mediterranean marine ecosystems: the example of the northeast Spanish littoral, Prog. Oceanogr., 44, 245-270, 1999.

Engel, A. and Passow, U.: Carbon and nitrogen content of transparent exopolymer particles (TEP) in relation to their Alcian Blue adsorption, Mar. Ecol.-Prog. Ser., 219, 1-10, 2001.

Gacia, E., Duarte, C. M., and Middelburg, J. J.: Carbon and nutrient deposition in a Mediterranean seagrass (Posidonia oceanica) meadow, Limnol. Oceanogr., 47, 23-32, https://doi.org/10.4319/lo.2002.47.1.0023, 2002.

Heinonen, K. B., Ward, J. E., and Holohan, B. A.: Production of transparent exopolymer particles (TEP) by benthic suspension feeders in coastal systems, J. Exp. Mar. Biol. Ecol., 341, 184195, https://doi.org/10.1016/j.jembe.2006.09.019, 2007.

Kiørboe, T. and Hansen, J. L. S.: Phytoplankton aggregate formation: observations of patterns and mechanisms of cell sticking and the significance of exopolymeric material, J. Plankton Res., 15, 993-1018, https://doi.org/10.1093/plankt/15.9.993, 1993.

Krom, M. D., Kress, N., Brenner, S., and Gordon, L. I.: Phosphorus limitation of primary productivity in the eastern Mediterranean Sea, Limnol. Oceanogr., 36, 424-432, 1991.

Marbà, N., Díaz-Almela, E., and Duarte, C. M.: Mediterranean seagrass (Posidonia oceanica) loss between 1842 and 2009, Biol. Conserv., 176, 183-190, https://doi.org/10.1016/j.biocon.2014.05.024, 2014.

Mari, X., Beauvais, S., Lemee, R., and Pedrotti, M.: Non-Redfield $\mathrm{C}: \mathrm{N}$ ratio of transparent exopolymeric particles in the northwestern Mediterranean Sea, Limnol. Oceanogr., 46, 1831-1836, 2001.

Mari, X., Passow, U., Migon, C., Burd, A. B., and Legendre, L.: Transparent exopolymer particles: Effects on carbon cycling in the ocean, Prog. Oceanogr., 151, 13-37, https://doi.org/10.1016/j.pocean.2016.11.002, 2017.

Mateo, M. A. and Romero, J.: Detritus dynamics in the seagrass Posidonia oceanica: elements for an ecosystem carbon and nutrient budget, Mar. Ecol.-Prog. Ser., 151, 43-53, 1997. 
Mateo, M. Á., Sánchez-Lizaso, J. L., and Romero, J.: Posidonia oceanica "banquettes": A preliminary assessment of the relevance for meadow carbon and nutrients budget, Estuar. Coast. Shelf S., 56, 85-90, https://doi.org/10.1016/S02727714(02)00123-3, 2003.

Myklestad, S. M.: Release of extracellular products by phytoplankton with special emphasis on polysaccharides, Sci. Total Environ., 165, 155-164, https://doi.org/10.1016/00489697(95)04549-G, 1995.

Ortega-Retuerta, E., Duarte, C. M., and Reche, I.: Significance of bacterial activity for the distribution and dynamics of transparent exopolymer particles in the Mediterranean sea, Microb. Ecol., 59, 808-18, https://doi.org/10.1007/s00248-010-9640-7, 2010.

Ortega-Retuerta, E., Sala, M. M., Borrull, E., Mestre, M., Aparicio, F. L., Gallisai, R., Antequera, C., Marrasé, C., Peters, F., Simó, R., and Gasol, J. M.: Horizontal and Vertical Distributions of Transparent Exopolymer Particles (TEP) in the NW Mediterranean Sea Are Linked to Chlorophyll $a$ and $\mathrm{O}_{2}$ Variability, Front. Microbiol., 7, 2159, https://doi.org/10.3389/fmicb.2016.02159, 2017.

Parsons, T. R., Maita, Y., and Lalli, C. M.: A manual of chemical and biological methods for seawater analysis, Pergamon Press, Oxford, UK, 1984.

Passow, U.: Transparent exopolymer particles (TEP) in aquatic environments, Prog. Oceanogr., 55, 287-333, https://doi.org/10.1016/S0079-6611(02)00138-6, 2002.

Passow, U. and Alldredge, A. L.: Aggregation of a diatom bloom in a mesocosm: The role of transparent exopolymer particles (TEP), Deep-Sea Res. Pt. II, 42, 99-109, 1995a.

Passow, U. and Alldredge, A. L.: A dye-binding assay for the spectrophotometric measurement of transparent exopolymer particles (TEP), Limnol. Oceanogr.-Meth., 40, 1326-1335, 1995 b.
Peduzzi, P. and Herndl, G. J.: Decomposition and significance of seagrass leaf litter (Cymodocea nodosa) for the microbial food web in coastal waters (Gulf of Trieste, Northern Adriatic Sea), Mar. Ecol.-Prog. Ser., 71, 163-174, 1991.

Prieto, L., Navarro, G., Cózar, A., Echevarría, F., and García, C. M.: Distribution of TEP in the euphotic and upper mesopelagic zones of the southern Iberian coasts, Deep-Sea Res. Pt. II, 53, 1314-1328, https://doi.org/10.1016/j.dsr2.2006.03.009, 2006.

Radić, T., Kraus, R., Fuks, D., Radić, J., and Pecar, O.: Transparent exopolymeric particles' distribution in the northern Adriatic and their relation to microphytoplankton biomass and composition, Sci. Total Environ., 353, 151-61, https://doi.org/10.1016/j.scitotenv.2005.09.013, 2005.

Simeone, S. and De Falco, G.: Morphology and composition of beach-cast Posidonia oceanica litter on beaches with different exposures, Geomorphology, 151-152, 224-233, https://doi.org/10.1016/j.geomorph.2012.02.005, 2012.

Simon, M., Grossart, H. P., Schweitzer, B., and Ploug, H.: Microbial ecology of organic aggregates in aquatic ecosystems, Aquat. Microb. Ecol., 28, 175-211, https://doi.org/10.3354/ame028175, 2002.

Thornton, D. C. O.: Formation of transparent exopolymeric particles (TEP) from macroalgal detritus, Mar. Ecol.-Prog. Ser., 282, 1-12, https://doi.org/10.3354/meps282001, 2004.

Zhou, J., Mopper, K., and Passow, U.: The role of surface-active carbohydrates in the formation of transparent exopolymer particles by bubble adsorption of seawater, Limnol. Oceanogr., 43, 1860-1871, 1998. 